\title{
ATOPIA - MIESTO KYNIKA VO SVETE
}

JAROSLAV CEPKO, Katedra filozofie, Filozofická fakulta Univerzity Mateja Bela, Banská Bystrica, SR

CEPKO, J.: Atopia - the Cynic's Place in the Universe FILOZOFIA, 75, 2020, No 3, pp. $170-182$

\begin{abstract}
The paper proposes a new interpretation of Cynic cosmopolitanism as a consequence of the philosophical way of life. Its characteristic of being "atopon" "out of place", meaning strange and at the same time not bound to a particular space, offers a possibility to explain the theoretic concept of cosmopolitanism by means of a practical stance. Moreover, the "strangeness" of philosophical life shows a fundamental link between Socrates' and Diogenes' philosophy.
\end{abstract}

Keywords: Ancient Cynicism - Diogenes of Sinope - Socratic philosophy - Atopia - Cosmopolitanism

Kynické hnutie býva interpretované na základe niektorého z pojmov jeho „doktrinálnej“ výbavy, o ktorom sa jednotliví komentátori domnievajú, že je klúčový a možno z neho odvodit' väčšinu zvyšného kynického pojmoslovia. Tak sa môžeme stretnút' s prístupom, ktorý na kynizmus - najmä na jeho najstarších predstavitel'ov Diogena a Kratéta, prípadne ich sokratovského prekurzora Antisthena - nahliada cez optiku

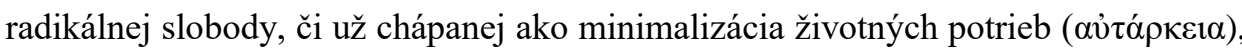
alebo ako úprimné až bezostyšné vyjadrovanie vlastného názoru ( $\pi \alpha \rho \rho \eta \sigma i ́ \alpha)$, prípadne naopak, považuje tieto dva aspekty za dôsledok kritiky vžitých hodnôt a noriem správania ( $\pi \alpha \rho \alpha \chi \alpha ́ \rho \alpha \xi 1 \varsigma)$, alebo úsilia žit' (priam animálne) v zhode s prirodzenost'ou

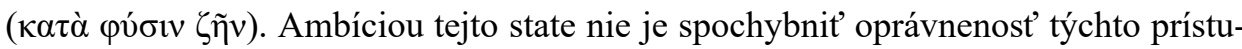
pov, ale upozornit' na to, že vysvetl'ovaním kynického spôsobu života na základe nejakého doktrinálneho prvku zrejme zamieňajú účinok s príčinou. Kynickí filozofi sa totiž svojim súčasníkom javili najmä ako prototypy istého spôsobu života a ak komunikovali nejakú „náuku“, tá bola výsledkom ich žitia, nie vice versa. Preto sa v d’alšom texte sústredím na pojem atopie, ktorý je síce z kvantitatívneho hladiska výskytu $\mathrm{v}$ textoch marginálny, má však potenciál postavit' spomínaný vzt'ah života a náuky takpovediac z hlavy na nohy. Možno na ňom totiž demonštrovat', ako sa z pôvodného označenia prejavov správania transformoval do doktrinálneho obsahu v podobe myšlienky kozmopolitizmu, ktorej pôvodcom má byt' podl'a antických správ práve kynik Diogenes, no nad'alej v plnej sile pôsobí aj v našej súčasnosti. Okrem tohto presahu 
do budúcnosti má kynická atopia ešte jednu vzácnu vlastnost'. Pri obhliadnutí do minulosti zarad'uje kynizmus do jednej línie s tým, ako niekol'ko desat'ročí pred Diogenom vnímali Aténčania filozofovanie „čudáckeho“ Sokrata.

\section{1. Čudný piknik na agore}

Zdá sa, že o tom, či sú kynici filozofmi, nemala grécka, helenistická ani rímska antika žiadne pochybnosti. V období cisárstva sa predstava filozofa $v$ bežnom povedomí spájala s postavami neupravených pouličných kazatel'ov, akých sa dalo stretnút' na uliciach hlavného mesta i v tých najodl'ahlejších provinciách. A predsa nás známy autor Životopisov významných filozofov Diogenes Laertský informuje, že nejestvoval jednoznačný konsenzus $v$ tom, či kynizmus možno zahrnút' medzi takzvané filozo-

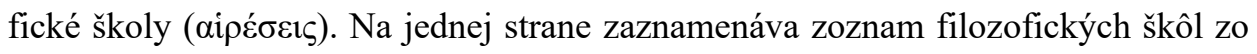
spisu Peri haireseón od Hippobota, autora z 2. storočia po Kristovi. (Diog. Laert. I 19 - 20), na strane druhej sám propaguje názor, že kynizmus nie je iba spôsob života

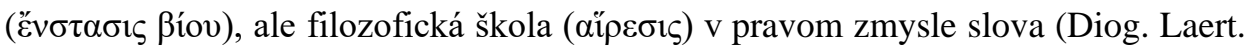
VI 103). ${ }^{1}$ To, čo sa ako problém mohlo javit' doxografom cisárskej doby, totiž napätie medzi pojmom filozofickej „školy“, ktorá odovzdáva nejakú teoreticky uchopitel'nú náuku, ktorú možno vyučovat', a filozofickým „spôsobom života“, nebol však problém v polovici 4. storočia pred Kristom, ked” „filozofovat" neznamenalo predovšetkým „,zastávat’ nejaký názor“, ale „formovat’ vlastný život““2

V prípade kynikov, a najmä Diogena, bol ich štýl života a vonkajšieho správania akiste mimoriadne nápadný. Nešlo iba o dojem, aký vzbudzoval u bežných l'udí, ale o vedomú vol'bu. Ked' Plutarchos opisuje Diogenovo duševné rozpoloženie pri zamyslení nad rozdielom medzi vlastným životom a životom ostatných, píše: „Diogenes sa krčil celý schúlený dakde na rohu námestia, snažil sa zaspat' a upadal do pochmúrnych a depresívnych myšlienok. Premýšl’al o tom, že ho vlastne nič nenútilo, aby si vybral tento bolestný a čudácky spôsob života, a že tu sám a zo svojej vôle sedí zbavený všetkého majetku“ (De prof. in virt. 5 [= SSR V B 172]). ${ }^{3}$ V tejto pochmúrnej nálade si Diogenes všimne bezstarostnú myš spokojnú s tým, čo nájde. Epizóda s myšou, moment Diogenovho filozofického „osvietenia“, pochádza podl’a Diog. Laert. VI 22 zo spisu Megarikos od Diogenovho súčasníka Theofrasta, čo jej pridáva na vierohodnosti. Plutarchova kvalifikácia Diogenovho správania ako „čudáckeho spôsobu

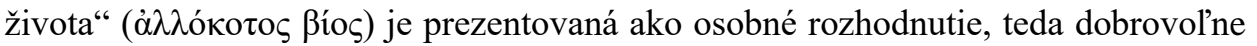

\footnotetext{
${ }^{1}$ Podrobnejšie k tejto problematike možno nájst’ v knihe Flachbartová (2015, 68 - 94).

${ }^{2} \mathrm{~K}$ interpretácii dejín antickej filozofie ako snahy o formovanie života porovnaj napr. Hadot (1995).

${ }^{3}$ Diogenove zlomky sú zozbierané v sekcií V B Giannantoniho edície sokratovských pozostalostí (1990, 2. zv., 227 - 510). Slovenský preklad s komentárom sa nachádza v práci Cepko, Kalaš, Suvák (2016).
} 
zvolený životný štýl. Diogenes Laertský (VI 22 [= SSR V B 172]) pri opise tej istej príhody používa $\mathrm{v}$ súvislosti $\mathrm{s}$ Diogenovou situáciou stoicky zafarbený pojem $\pi \varepsilon \rho i ́ \tau \tau \alpha \sigma \iota$, ktorý znamená náhodnú okolnost', v ktorej sa človek ocitá či už vlastným pričinením, alebo bez neho. Myš Diogenovi ponúkla interpretačný klúč k vlastnému životu: aj on totiž náhodnú situáciu, život vyhnanca, premenil na osobnú vol'bu. Už to nie je tak, že „veci sa dejú s Diogenom“, ale ich akceptovaním sa on sám stáva pánom svojho života, nech to vonkajším pozorovatel'om pripadá akokol'vek zvláštne.

Zvláštnost' Diogenovho života a správania je zachytená aj v zlomku od Diog. Laert. VI 69 [= SSR V B 147], v ktorom sa viackrát vyskytuje termín ö́o rom sa zdržíme dlhšie:

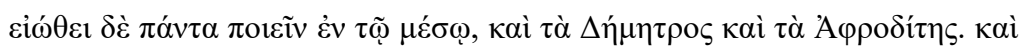

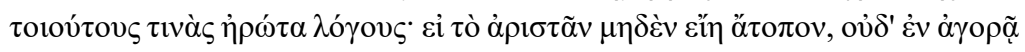

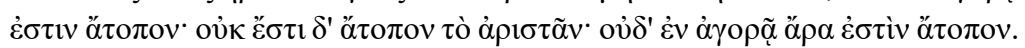

[Diogenes] mal vo zvyku všetko robit' na verejnosti - požívat' jedlo, ale aj pôžitky Afrodity. Svoje počínanie zdôvodňoval asi takto: Keby raňajkovat' nebolo nič neslušné, nebolo by to neslušné ani na námestí. Raňajkovat' však naozaj nie je nič neslušné, a preto nie je neslušné robit' to na námestí. ${ }^{4}$

Pasáž sa v rámci kynikovho životopisu nachádza ku koncu zbierky chreii, ${ }^{5}$ po ktorej nasleduje dlhší doxografický súhrn Diogenových názorov na rôzne témy (Diog. Laert. VI 70 - 74). Jadrom zlomku je paródia na sylogizmus, ktorý má ospravedlnit' Diogenovo správanie. Životopisec naznačuje, že pre Diogena bolo typické zámerné stieranie hraníc medzi činnost'ami verejnými, ktoré je prípustné robit' uprostred l'udí ( $\dot{\varepsilon} v \tau \tilde{\omega}$ $\left.\mu \varepsilon \sigma_{(} \omega\right)$, a privátnymi záležitost’ami, ktoré sa zvyknú vykonávat' v priestoroch chránených pred cudzími pohl'admi. Tie druhé sú konkretizované ako veci Demetry a Afrodity

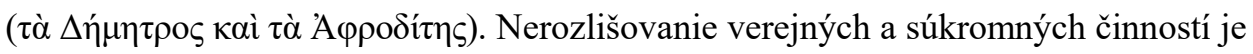
nerozlučne späté s popieraním rozdielu medzi verejnými a privátnymi priestormi. Jednoducho povedané, kynik si z agory robí svoju kuchyňu, jedáleň, kúpelňu i toaletu. Svoje konanie označuje adjektívom ớtođov, o ktorom sme oprávnení domnievat' sa, že ho Diogenes neraz počul ako výčitku na adresu svojho správania. Po etymologickej stránke pochádza zo substantíva negované pomocou alpha privativum. V prvom pláne teda adjektívum ö́ođov označuje niečo, čo je vyňaté z priestorového rámca a v prenesenom zmysle označuje niečo,

\footnotetext{
${ }^{4}$ Preklad A. Kalaš. V pôvodnom texte je výraz „požívat’ jedlo“ vyjadrený ako „záležitosti Demetry“ v paralele so „záležitost’ami Afrodity“.

${ }^{5}$ Chreia je krátky, typicky kynický žáner, ktorý obsahuje výrok alebo opisuje gesto v konkrétnej situácii a má etické posolstvo. Bližšie Flachbartová $(2015,30$ - 31).
} 
čo sa vymyká bežnému, vžitému, normálnemu ako „čudné“, „zvláštne“. 6 Zhodou okolností takéto prelínanie priestorovej a konvencionálnej (a morálnej) dimenzie je vyjadrené aj v slovenskom prídavnom mene „nemiestne“.7 Kalašov preklad „neslušné“ zdôrazňuje onen druhý, v súvislosti s Diogenom iste významnejší sémantický odtieň.

Ak však chceme pochopit', o čo Diogenovi ide, nesmieme zabúdat' na práve naznačenú významovú ambivalenciu. Pre toho, kto uznáva, že existujú vhodné a nevhodné miesta pre „slušné“ a „neslušné“ veci, bude argument síce formálne platný, ale zároveň bude trpiet' chybou viacznačnosti použitého termínu atopon. ${ }^{8}$ Spolu s R. B. Branhamom $(1996,94)$ ho možno rozpísat' takto:

Ak raňajkovanie nie je atopon [čudné], tak raňajkovanie nie je atopon [na nesprávnom mieste] ani na námestí.

Raňajkovanie nie je atopon [čudné].

Raňajkovanie nie je atopon [na nesprávnom mieste] ani na námestí.

Argument teda nie je správny ani presvedčivý, je to len karikatúra analytického nástroja teoretizujúcich filozofov, jedna zo zbraní Diogenovho antiteoretického arzenálu. Práve paródiu a humor zapojený do útoku na konvencie považuje Branham (1996, 93 - 95) za nosný pilier kynickej rétoriky. Ako ukážkové príklady cituje dve paródie na sylogizmy, prvý o mudrcoch ako priatel'och bohov, ktorého záver má podl'a Branhama ospravedlňovat' kynickú prax krádeží v chrámoch (Diog. Laert. VI 37 [= SSR V B 353]), ${ }^{9}$ a druhou je naša chreia o vhodnosti raňajkovania na agore (Diog. Laert. VI 69 [= SSR V B 147]). Ak Branham naozaj zachytil dôležitý rys diogenovskej rétoriky, tak zlomky, $\mathrm{v}$ ktorých dochádza $\mathrm{k}$ parodizácii sylogistického usudzovania, budú pod hrubými vrstvami diogenovskej legendy indikátormi, že by mohlo íst' o dicta historického Diogena, alebo aspoň o materiál s vyššou mierou dôveryhodnosti.

\footnotetext{
${ }^{6}$ Štandardný grécko-anglický lexikón pri hesle ő̃o out of the way: hence [1.] unwonted, extraordinary; strange, paradoxical, absurd, unnatural, disgusting, foul, monstruos, wicked, bad, harmful; [2.] non-spacial“"(Liddell, Scott, Jones 1968, 273). Sub-

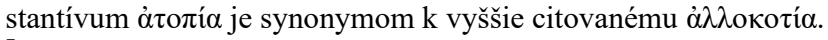

${ }^{7}$ Porovnaj aj slangové „byt' mimo“.

${ }^{8}$ Chybu na základe homonymie demaskuje Aristoteles v Soph. elench. 165b - 166a ako prvú z argumentačných chýb, ktoré sú založené na slovnom vyjadrení.

${ }_{9}^{9}$ Porovnaj Cepko (2016).
} 
Ako bojovník proti vžitým názorom ( $\delta o ́ \xi \alpha \imath)$ a konvenčnosti $(v o ́ \mu \circ)^{10}$ si Diogenes berie na mušku formálne filozofické usudzovanie, ktoré je najkonvenčnejšou podobou myslenia, a zároveň rituály, ktoré sú najkonvenčnejšou podobou praxe (Branham 1993, 95). V sledovanej chreii sú zlúčené oba tieto terče. Vyššie sme videli, ako kynik zosmiešňuje sylogizmus, a teraz sa pozrime, ako zosmiešňuje rituálnu prax. Diogenes vystupuje proti rôznym druhom rituálov: náboženským (modlitba, očist'ovanie, obety) ${ }^{11}$ i tým, ktoré majú sekulárnejší podtext (sexuálne a dietetické tabu). ${ }^{12}$ Zdá sa, že Diogenovi naozaj prekážajú rituály nie v tej či onej oblasti, ale nakol'ko sú rituálmi, a teda stelesneniami nоти.

Čo je však zlé na jedení na verejnom priestranstve? ${ }^{13} \mathrm{Z}$ pohl’adu dnešného človeka zvyknutého na pikniky v parkoch to vyzerá na nevinnú aktivitu, no je možné, že išlo o porušenie nejakého dobového tabu, a teda o prejav kynikovej bezostyšnosti. Je možné, že hoci Diogenovým súčasníkom nebolo neznáme spoločné verejné stolova-

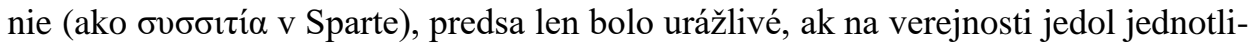
vec. Od jednotlivcov sa očakávalo, že budú stolovat' za múrmi svojho domu (Desmond 2008, 88). R. Geuss $(2001,13$ - 18) vyratúva tri dôvody, prečo takáto prax mohla vzbudzovat' odpor a rozhorčenie. Ako prvý uvádza takzvaný „princíp nevšímavosti“, pri ktorom sa na verejných miestach očakáva, že jednotlivec sa bude správat' tak, aby nevzbudzoval pozornost' l'udí, ktorí sa navzájom nepoznajú a nevedia, kto má aké zvyky, vkus a názor na to, čo sa patrí a čo nie. Druhým je ,princíp obavy z vyvolania závisti“. Na verejnom priestranstve sa môžu nachádzat' l’udia, ktorých sa môže dotknút', že niekto uspokojuje svoje potreby (v oblasti Demetry, rovnako ako v oblasti Afrodity), ktoré oni sami majú neuspokojené. Tretí by bolo možné nazvat' „princíp rozlišovania čistého a nečistého“. Voči tomu, čo je považované za nečisté, majú l'udia tendenciu reagovat' pestrou škálou reakcií, od odvrátenia pohl'adu po krajný odpor až telesnú nevol'nost'.

Aby som sa vrátil k otázke, čo je zlé na jedení na agore, nazdávam sa, že nemusíme siahat' po predpoklade existencie nejakých tabu v tejto oblasti. Naopak, dovolím

\footnotetext{
${ }^{10}$ Porovnaj sumarizáciu Diogenových postojov v Diog. Laert. VI 38 [= SSR V B 7]: ,[Diogenes] kládol odvahu do protikladu voči náhode, prirodzenost' voči zákonu, rozum voči citu."

${ }^{11}$ Napríklad SSR V B 339, 342, 344.

12 Napríklad incest, ktorý mohol byt' témou tragédie Oidipus, a kanibalizmus, na ktorý Diogenes narážal v tragédii Thyestes (SSR V B 132, 134). Porovnaj Hook 2005, 26 - 32.

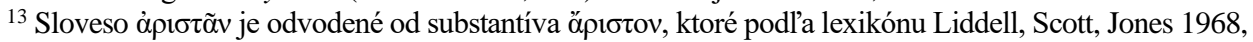
241 najskôr (u Homéra) označovalo prvé jedlo dňa, čiže raňajky. Neskôr (príklady u Herodota, Thukydida

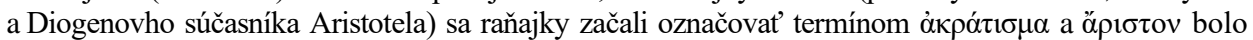
druhé jedlo dňa, čiže obed. Azda by bolo preto správnejšie preložit” „obedovanie“. Rešpektujem však Kalašov i Branhamov preklad (breakfast) a nepokladám za dôležité určit', o ktoré jedlo dňa išlo; pointou je totiž ,jedenie“ na verejnom priestranstve.
} 
si predpokladat', že išlo o pomerne nevinný a neškodný prehrešok. Diogenes si ho vybral iba preto, aby na tomto príklade založil zovšeobecnenie. Raňajkovanie nie je naozaj nič zvláštne (atopon), je to najnevinnejšia z Demetriných záležitostí. Lenže Diogenes spomína raňajkovanie preto, lebo to, čo platí o raňajkovaní, chce rozšírit' aj na ostatné veci, ktoré sú pod Demetriným patronátom, vrátane vylúčenia rezíduí, ktoré metabolizmus nebol schopný spracovat'. Rozlišovanie čistého a nečistého, o ktorom píše Geuss, má totiž zvyčajne do činenia s látkami, ktoré prestupujú hranicami stanovenými l’udským telom: vstupujú a/alebo vystupujú. A to je to, čo spája oblast' Demetry s oblast'ou Afrodity. V našom sylogizme Diogenes orientuje svoje zovšeobecnenie z nevinnej aktivity na tie odpudzujúcejšie a poburujúcejšie. V správe, ktorú životopisec uvádza hned' nato, je postup opačný, od poburujúceho k tomu, čo je akceptovatelné, od Afrodity k Demetre: „Často na verejnosti ,pracoval rukou'. Zvykol pri tom hovorit: ,Prial by som si, aby bolo možné aj hlad zahnat' pošúchaním brucha.““(Diog Laert. VI 69 [= V B 147]). Odkaz na Demetru a Afroditu pred citovaním Diogenovho sylogizmu indikuje, že obe správy patria $\mathrm{k}$ sebe. Životopisec nám tým dáva do rúk interpretačný klúč ku chreii o raňajkovaní: Tak ako je jedno, či sa raňajkuje v súkromí alebo na verejnosti, je tiež jedno, kde sa vykonávajú aktivity, ktoré sú prirodzeným dôsledkom požitia jedla, a je jedno, kde sa vykonáva čo najjednoduchšie uspokojovanie sexuálnych potrieb. A to ešte nie je všetko. Ak už čítame chreiu takto odzadu, to najpoburujúcejšie, to, čo je najviac atopon, je zmienené na jej úplnom začiatku: je

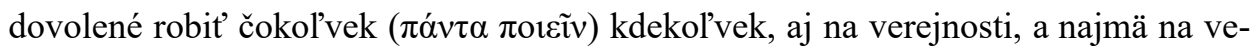
rejnosti, doslova „V strede“ ( $\dot{\varepsilon} v \tau \tilde{\omega} \mu \varepsilon \dot{\varepsilon} \sigma \omega)$, pred očami l'udí, ktorí sú kynikovým publikom, aby ich naučil, že hranice v priestore ani v morálke nemajú byt' určované konvenciou, ale rozumným žitím podla prirodzenosti. Kynik žije mimo takýchto konvenčných hraníc, preto sa jeho život odohráva v znamení atopie.

\section{Sokrates, ktorému preskočilo}

Napriek výstrednosti, s akou Diogenes vedie svoj život, jeho extravagantné správanie možno chápat' ako dovedenie do dôsledkov toho, ako boli vnímané osoby, ktoré sa oddali „filozofovaniu“. Hoci sloveso $\varphi$ ı doložit' už v staršom období, ${ }^{14}$ ich užívanie je pred koncom 5. storočia pred Kristom pomerne vzácne. So začiatkom 4 . storočia sa však s ich výskytmi priam pretrhlo vrece a tento fenomén si nedokážeme vysvetlit' inak ako tým, že zo slova filosofein si urobil takpovediac svoju značku aténsky občan Sokrates. ${ }^{15}$ Literárne obrazy Sokrata, ktoré

\footnotetext{
${ }^{14}$ Podl'a tradície sa mal slovom „filozof“ ( 12). O pytagorovskom pozadí sokratiky a kynizmu porovnaj Škvrnda 2016 a 2019.

${ }^{15}$ L. Rossetti $(2010,59)$ pripomína, že pred koncom 5. storočia pred Kristom možno výskyty rátat' v niekol'kých desiatkach, od začiatku 4. storočia pred Kristom je to už v stovkách.
} 
sa nám zachovali z produkcie jeho poslucháčov, ukazujú, že „filozofovanie“16 nieslo so sebou vo vel'kej miere vyčlenenie z toho, čo bolo vnímané ako zvyčajné, bežné, normálne.

V takomto svetle nám Sokratovo postavenie v aténskej spoločnosti vykresl'uje aj Platón, ktorého sociálny i majetkový status bol pomerne stabilný na to, aby sa v nejakom ohl'ade považoval za vydedenca. V Obrane Platón Sokratovými ústami tvrdí, že práve filozofovanie prinieslo tomuto radovému aténskemu občanovu bil'ag niekoho, kto stojí mimo komunity - ,ja“ a „vy, mužovia aténski“ je základná kontrapozícia, ktorá zaznieva v jeho troch rečiach pred zhromaždením sudcov. V dialógu Gorgias posledný z diskutujúcich, Kalliklés, hovorí Sokratovi, že filozofovanie je dobré iba pre mladých, v staršom veku sa však filozofi odcudzujú spoločenstvu a stávajú sa smiešnymi, pretože bl'abocú ako deti, hoci det'mi už nie sú $(484 \mathrm{c}-485 \mathrm{c}) \cdot{ }^{17}$ Hoci

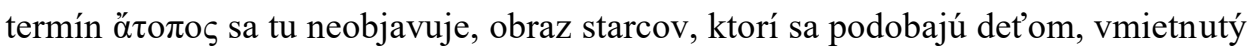
do tváre postaršieho Sokrata, jasne evokuje výčitku nenáležitosti a nemiestnosti. Napokon, ked'sa Sokrates Theaitétovi v rovnomennom dialógu priznáva k tomu, že ovláda pôrodnícke umenie, potichu dodáva, že l’udia o tom nevedia, ale hovoria

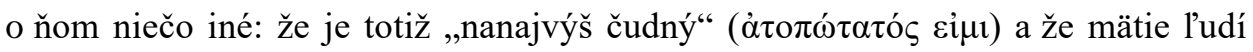

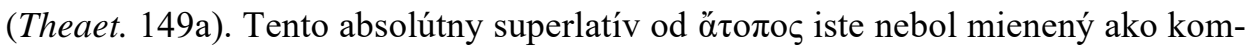
pliment. Vyjadruje mienku Aténčanov a tým, že Platónov Sokrates túto mienku vyslovuje v prvej osobe, berie ju za svoju. Za „,̌udné“ (Symp. 175b) je označené aj Sokratovo správanie na začiatku Sympózia, ked’ Aristodémos privedie Sokrata k Agatónovmu domu a zrazu si všimne, že Sokrates nie je s ním - zablúdil k susedom a stál u nich v dome bez pohnutia a nereagoval na volanie. Aristodémos ho ospravedlňuje tým, že sa mu to stáva často.

Ked' sa niekol'ko desat'ročí po Sokratovej smrti v Aténach objavil Diogenes, obyvatelia mesta si jeho životný štýl okamžite museli spojit's oným filosofein, ktoré reprezentoval Sokrates. Medzi týmito dvoma filozofickými postavami existujú, samozrejme, rozdiely. Sokrates bol aténsky občan, k Aténam cítil vel'mi silné puto, bojoval za ne s ostatnými spoluobčanmi vo vojne a v posledných dňoch pred popravou sa $\mathrm{v}$ rozhovore so svojím rovesníkom Kritónom vyznáva $\mathrm{z}$ úcty $\mathrm{k}$ aténskym zákonom. Hoci vel’a času trávil na agore, mal aj svoju domácnost', manželku a deti. Jeho atopia

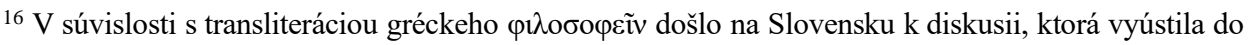
úsilia o odlíšenie neskoršej, teoreticky orientovanej „filozofie“ od pôvodnej, praktickej a na stvárňovanie života zameranej „filosofie“ (Suvák 2000). V tomto príspevku rešpektujem úzus, podl’a ktorého sa písanie tohto slova prispôsobuje slovenskej výslovnosti, pritom ale súhlasím s potrebou odlišovania medzi antickou (a zvlášt' sokratovskou) filozofiou ako umením formovania života a neskorším (i súčasným) chápaním toho istého slova.

${ }^{17}$ V tejto krátkej pasáži zaznieva až štyrikrát, že filozofi a filozofovanie v staršom veku si zaslúžia

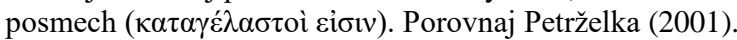


sa týka výlučne spôsobu života, inak Sokrates zostáva konformný so svojou dobou, v ktorej si naplnený život nebolo možné predstavit’ bez väzby na polis. ${ }^{18}$ U Diogena sa atopia taktiež prejavuje spôsobom života - a azda ani netreba uvádzat' dôkazy toho, že jeho prejavy boli ešte čudáckejšie, ostentatívnejšie a provokujúcejšie ako Sokratove. Je tu však ešte jedna dôležitá skutočnost', ktorá z Diogena robí priam živý symbol a stelesnenie atopie. Diogenes je v Aténach cudzí. Nie je domáci, ale prišelec. Pôvodom je zo Sinópy, mesta na maloázijskom pobreží Čierneho mora. Podl'a antických správ mala byt' príčinou jeho odchodu peňazokazecká aféra, do ktorej sa namočil so svojím otcom Hikesiom (Diog. Laert. VI 20 - 21 [= SSR V B 2]). Sinópu teda opúšt’a bud' ako vyhnanec, alebo ako utečenec. Prečo sa dostáva práve do Atén, nie je celkom jasné. Každopádne, na novom mieste začína žit' filozoficky a do tohto spôsobu života sa pokúša integrovat' aj svoju ,,vykorenenost““': nemá svoju domácnost', nemôže dúfat' ani v nadobudnutie statusu občana. Diogenes sa zvyčajne zdržiaval na verejných priestranstvách (Diog. Laert. VI 22 [ = SSR V B 174]) a dostal sa do povedomia vd’aka označeniu „filozof v sude“ (Diog. Laert. VI 23 [= SSR V B 174]). V skutočnosti nešlo o drevený sud, aký sa objavuje v neskoršej ikonografii. Diogenovým

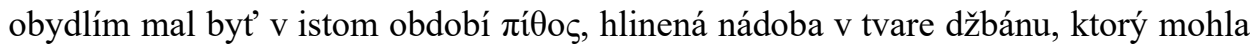
mat' rozmery dost' vel'ké na to, aby v nej Pes Diogenes mohol bývat' ako vo svojej búde (Desmond 2008, 83). Možno nie je bez zaujímavosti, že v dávnejšej dobe pithos slúžil aj na pochovávanie (Osborne 2009, 44 - 45). Ak môžeme predpokladat', že $\mathrm{v}$ povedomí Aténčanov ešte žila táto asociácia, Diogenov pithos azda nebol iba narážkou na absenciu domova, ale najmä na odcudzenost' voči svetu žijúcich. Možno si predstavit' vyššiu mieru atopie?

Diogenes Laertský (VI 54 [= SSR 59]) píše, že Diogena ktosi počastoval označením ,šalejúci Sokrates“ ${ }^{19}$ G. Giannatoni upozorňuje, že z textu, ktorý uvádza životopisec, nie je jasné, kto sa koho pýtal na názor na Diogena (1990, 4. zv., 434 - 435). Od Ailiana (Var. hist. XIV 33 [= SSR 59]) sa dozvedáme, že prezývka mala pochádzat' od Platóna. V kontexte údajnej rivality medzi Platónom a Diogenom sa toto označenie zvykne interpretovat' ako Platónovo odsúdenie Diogenovho filozofovania ako nesokratovského. Keby sme si však dovolili predpoklad, že „„̌alejúci Sokrates“ bola prezývka, ktorá vzišla z radov obyvatel'ov mesta, ktorí mali možnost' pozorovat' a porovnávat' život oboch mužov oddaných filozofii, mohli by sme príst' k záveru, že Diogenes sa nelíši od čudáckeho Sokrata v druhu, ale skôr v stupni. Sinópčan len dot’ahuje do krajných konzekvencií to, čo Sokrates inicioval ako filozofický spôsob života.

\footnotetext{
${ }^{18}$ V tomto ohl'ade sa nič nezmení ani u Platóna a Aristotela, ktorých politická koncepcia nepresahuje rámec gréckej obce klasickej doby.

19 Dôkladnejšiu analýzu a hlbšie interpretácie môže čitatel' nájst' u Flachbartovej (2015, 95 - 160); u Cepka, Kalaša, Suváka (2016, 89 - 91).
} 


\section{Forma pretavená do obsahu}

$\mathrm{Z}$ doteraz napísaného je zrejmé, že filozofická, a teda aj kynická atopia je charakteristikou životnej formy. Na začiatku sme uviedli, že v kynickom hnutí je primárny spôsob života, čo však kynizmus nediskvalifikuje ako filozofiu, ale práve naopak. Atopia filozofického života sa v Diogenovom prípade javí ako príklad toho, ako sa modus vivendi a modus operandi transformujú do pozitívnej náuky. Diogenovo „čudáctvo“ sa tak stáva nástrojom prehodnocovania hodnôt podl’a hesla „falšovat' obe-

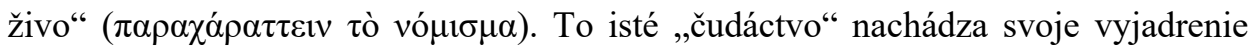

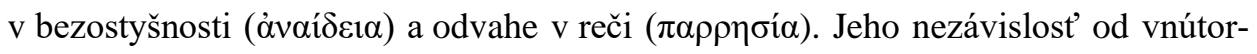
ných i vonkajších tlakov, spochybnenie a prekročenie dichotómií občan-neobčan, majetný-nemajetný, domáci-cudzí, vládnuci-ovládaný je prejavom slobody chápanej ako

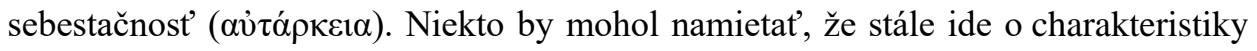
spojené s prejavmi života a správania. Tradícia však Diogena považuje za vynálezcu mimoriadne životaschopného teoretického konceptu - kozmopolitizmu.

Klúčovým svedectvom je v tomto prípade Diog. Laert. VI 63 [= SSR 355]: „Ked’

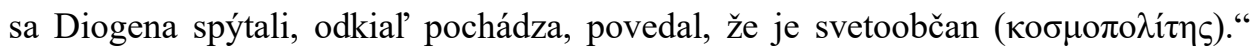
Otázka, či je Diogenovo autorstvo tejto myšlienky historicky vierohodné, a ak áno, čo mohlo byt' jej pôvodným obsahom, komentátorov rozdeluje. ${ }^{20}$ Počnúc Dudleym až do konca minulého storočia prevládal názor, že myšlienka kozmopolitizmu je až neskoršia, konkrétne stoická, a že ak Diogenes zastával myšlienku svetoobčianstva, tak iba v čisto negatívnom zmysle, teda ako odpútanost' od akejkol'vek historicky ukotvenej formy spoločenstva a vlasti. ${ }^{21}$ Táto interpretácia vychádza z predpokladu, že sám kynizmus je výlučne negatívna filozofia, teda že jeho podstata sa vyčerpáva v kri-

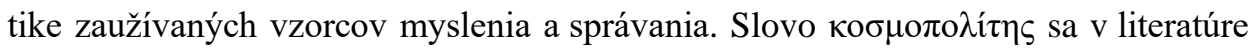
prvý raz objavuje na prelome letopočtov u stoicizujúceho a platonizujúceho židovského exegétu Filóna z Alexandrie (De opif. mundi 142). Lukianos (Vit. auct. 8 [=SSR V B 80]) a Diogenes Laertský vo vyššie citovanej pasáži ho pripisujú Diogenovi až neskôr. Núka sa preto predpoklad, že ide o prenesenie stoického konceptu na nášho kynika; kynizmus bol koniec koncov v období helenizmu všeobecne považovaný za kolísku stoicizmu a stoik Zenón mal svoju Ústavu - dielo, ktorého obsahom mohli byt’ aj kozmopolitné myšlienky - napísat' „na psom chvoste“, čiže ako žiak kynika Kratéta (Diog. Laert.

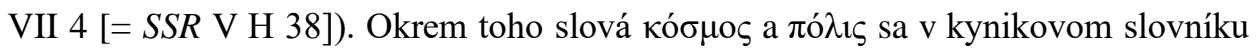
vyskytujú iba v kontexte polemiky s tými, čo sa oddávajú fyzikálnym špekuláciám

\footnotetext{
${ }^{20}$ Prehl’ad protichodných interpretácií sa nachádza v práci Cepko, Kalaš, Suvák (2016, 288 - 292).

${ }^{21}$ O takzvanom negatívnom kozmopolitizme u Diogena píšu Dudley (1937, 35); Giannantoni (1990, 4. zv., 544); Goulet-Cazé (1982, 229 - 231); Schofield (1991, 141 - 145); Geuss (2001, 29); Haslanger (2015, 36); s výhradami Long $(2008,54)$.
} 
a strácajú tým čas, ktorý by mali venovat' ceste za zdatnost'ou (SSR V B 370 - 374). A napokon, Diogenes je taký individualista, že záujem o l’udské spoločenstvo, ešte $\mathrm{k}$ tomu celosvetových rozmerov, uňho sotva možno predpokladat'. Kozmopolitizmus v zmysle popierania príslušnosti k vlasti možno doložit aj u sokratovca Aristippa, ${ }^{22}$ ktorému Xenofón v Mem. II 1, 13 [= SSR IV A 163] kladie do úst slová: „Neviažem sa na jednu obec, ale všade som cudzincom.“

Tak by sa zdalo, že hypotéza o „negatívnom kozmopolitizme“ má svoje ratio. Koniec koncov aj náš predpoklad, že kynikov koncept kozmopolitizmu vychádza $\mathrm{z}$ atopickej formy filozofického života, by smeroval $\mathrm{k}$ takémuto záveru. V zlomku V B 263 G. Giannantoni zoskupil svedectvá od piatich antických autorov (Diog. Laert. VI 38; Gnom. Vat. 743 n. 201; Aelian. Var. hist. III 29; Iulian. Orat. VI [= Epist. ad Themist. ] 4 p. 256 D a Orat. IX [= VI] 14 p. 195 B; Epict. Dissert. III 22, 47), ktoré s Diogenom spájajú verše z tragédie. Uved’me verziu od Diogena Laertského:

Diogenes hovorieval, že ho v živote stretli kliatby tragédie. Je vraj totiž:

bez vlastného mesta, bez domova a bez vlasti,

bedár, tulák, čo živobytie má len na jeden deñ. ${ }^{23}$

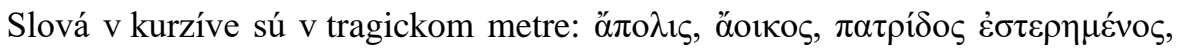

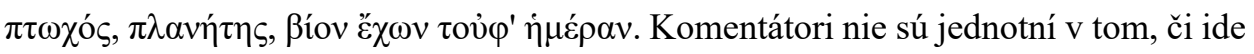
o verše z tragédie, ktorú napísal Diogenes sám, alebo či len cituje iného autora. ${ }^{24} \mathrm{Na}$ jednej strane sa totiž Diogenovi pripisuje autorstvo viacerých paródií na tragédie (Diog. Laert. VI 80 [= SSR V B 117]), na druhej strane ku kynikovmu prejavu patrilo aj žartovné využívanie citátov z Homéra a iných básnikov (SSR V B $492-500$ ). Pre nás sa v súvislosti s témou atopie javia ako zaujímavé prvé dve adjektíva, vytvorené zo slov vyjadrujúcich miesto, $\pi$ ó $\lambda$ ıৎ a oĩkos, pomocou alpha privativum, čo je rovnaká štruktúra ako pri adjektíve ö́ođos. Zdá sa, že ide o d’alšie potvrdenie Diogenovho „negatívneho kozmopolitizmu“. Znamenalo by to, že kynik vlastne nemá vo svete žiadne miesto. Máme sa tu zastavit?

${ }^{22}$ Cicero ako o „obyvatel’ovi a občanovi sveta“ (mundi incolam et civem) hovorí dokonca aj o Sokratovi (Tusc. disp. V 108). Otázke, či Sokrates bol alebo nebol kozmopolitom ante litteram sa venuje Pangle (1998).

${ }^{23}$ Preklad A. Kalaš.

${ }^{24}$ B. Snell (Nauck, Snell 1964, 893 - 894) vo svojej zbierke zlomkov gréckych tragikov zarad'uje tieto verše ako zl. 284 medzi pozostalosti od neznámych autorov (adespota), pripomína však, že staršia kritika zlomok pripisovala Euripidovi; porovnaj slová z Euripidovho Hippolyta 1029: „bez

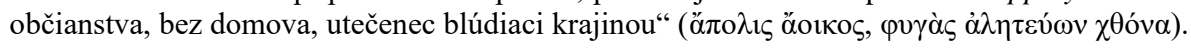




\section{4. $Z$ diváka herec}

Nazdávam sa, že by sme tým podcenili dosah Diogenovej rétorickej stratégie. Sotva si dokážeme predstavit', že ak Diogenes citoval tieto tragické verše, robil to zo zatrpknutosti a iba sám pre seba. Kynická rétorika má totiž dva aspekty, na ktoré poukázali Branham (1996) a Bosman (2006): humor a performatívny charakter. Stav „bez občianstva“ a „bez domova“ sú nepríjemné okolnosti, v ktorých sa kynik ocitá. Sú jeho situáciou ( $\pi \varepsilon \rho i ́ \sigma \tau \alpha \sigma ı \varsigma)$, s ktorou sa vyrovnáva tak, že ju akceptuje a mení na svoju výhodu. Vd'aka humoru a nadl'ahčeniu sa stáva pre kynika znesitel'nou a zároveň vd’aka tomu istému humoru, či už ostrému diogenovskému výsmechu alebo vlúdnejšiemu kratétovskému vtipu, sa kynická technika stvárňovania vlastného života šíri medzi tých, čo sa prizerajú.

Prvému „filozofovi“, Pytagorovi, sa pripisuje dictum, v ktorom prirovnáva život k sviatku spojenému s rôznymi druhmi sút’aží ( $\pi \alpha v \eta ́ \gamma v \rho ı \varsigma)$. Jedni počas neho sút'ažia, iní prišli za obchodmi, no podl’a Pytagora najlepšiu rolu zo všetkých majú „diváci“, ktorých stotožňuje s filozofmi (Diog. Laert. VIII 8). Filozofická atopia v takejto perspektíve znamená, že filozof si vytvára odstup od sveta, stavia sa mimo sveta; ten je preňho iba javiskom, ktoré pozoruje s blaženou rezervovanost'ou. Atopia kynického filozofa je iná. Ako možno vyčítat' z chreie o jedení na agore, kynik na jednej strane demonštruje svoju extravagantnost', frapantne dáva najavo, že nežije ako väčšina, no táto demonštrácia má svoje miesto. Odohráva sa uprostred druhých, pred ich očami, „,na verejnosti“, $\dot{\varepsilon} v \tau \tilde{\omega} \mu \varepsilon \dot{\varepsilon} \sigma \omega$. A tento „stred“ ( $\mu \varepsilon \dot{\sigma} \sigma \varsigma \varsigma)$ je kynikovo miesto vo svete, miesto, kde môže, ba musí „robit’ všetko“. Stojí na javisku sveta ako herec, komediant, ktorý svojím „čudáctvom“ falšuje obeživo: podla neho nie je čudný on, ale čudní sú všetci, ktorí strácajú čas zbytočnost’ami a pripisujú hodnotu tomu, čo v skutočnosti hodnotu nemá.

Hoci Diogenov kozmopolitizmus bezpochyby má primárne negatívny obsah, nájdu sa autori, ktorí mu pripisujú aj pozitívnu náplň. Proti väššinovej interpretácii sa o to vo svojich príspevkoch usilujú J. L. Moles (1996) a P. R. Bosman (2007). ${ }^{25}$ Výraz „,svetoobčan“ možno podl'a Bosmana akceptovat' ako skutočný „Diogenov neologizmus“ (2007, 29), pretože sa vel'mi dobre zhoduje s kynikovým paradoxným a ironickým vyjadrovaním a s jeho misijným poslaním. Ten istý autor d’alej konštatuje, že viac než neskorší výmysel je Diogenov kozmopolitizmus skoršia kuriozita, ktorá predbehla svoj čas $(2007,26)$. Kynik nie je l'ahostajný voči druhým l’ud’om, naopak, hladá s lampášom v ruke za bieleho dňa v neforemnom dave človeka, svojho spoluobčana $v$ štáte, ktorého nemožno topograficky vymedzit', pretože ide o neviditel'ný, vnútorný stav charakteru. Takéto kynické spoločenstvo nie je prostou sumou všetkých

${ }^{25}$ Dávnejšie pred oboma autormi pozitívny obsah kynického kozmopolitizmu obhajoval R. Höistad $(1948,142)$. 
l'udí na celom svete, ale spoločenstvo l'udí formujúcich svoje životy tak ako Diogenes. Kynická atopia má takto namierené k utópii.

\section{Záver}

Mali sme možnost' sledovat', ako sa atopia, to znamená „čudnost““, „,nemiestnost““ filozofického života u kynika Diogena transformovala do myšlienky svetoobčianstva. Tá neskôr zaznamenala svoje rozvinutie u stoikov, jej ozveny u novozákonných autorov mali vplyv na krest’anské myslenie patristiky i celého stredoveku a cez úvahy osvietencov sa stala neoddelitel'nou súčast'ou ideového inventára, ktorý sme zdedili. Isteže, každá zo spomínaných etáp vniesla do konceptu kozmopolitizmu nejaký nový akcent, prevládla však myšlienka účasti na l’udskom spoločenstve globálnych rozmerov. No na rozdiel od antropocentrického rozmeru, ktorý do kozmopolitizmu vniesli stoici, Diogenov kozmopolitizmus bol pravdepodobne širší a radikálnejší v tom, že prelamoval hranice medzi l'udským a živočíšnym, ba integroval aj neživú sféru živlov. ${ }^{26}$ Diogenes nás okrem toho učí, kde je miesto filozofa aj v našej dobe: „mimo“ a súčasne „V strede“, tak ako pithos čudáka Diogena pri Metroe na agore, ${ }^{27} \mathrm{v}$ politickom epicentre Atén.

\section{Literatúra}

BOSMAN, P. R. (2006): Selling Cynicism: The Pragmatics of Diogenes' Comic Performances. The Classical Quarterly, 56 (1), 93 - 104. DOI: https://doi.org/10.1017/S0009838806000085

BOSMAN, P. R. (2007): Citizenship of the world - the Cynic way. Phronimon, 8 (1), 25 - 38.

BRANHAM, R. B. (1996): Defacing the Currency: Diogenes' Rhetoric and the Invention of Cynicism. In: Branham, R. B. - Goulet-Cazé, M.-O. (eds.): The Cynics. The Cynic Movement in Antiquity and Its Legacy. Berkeley; Los Angeles; London: University of California Press, 81 - 104.

CEPKO, J. (2016): „Všetko patrí múdrym“" blasfémia, alebo utópia? Filozofia, 71 (2), 131 - 140.

CEPKO, J., KALAS̆, A., SUVÁK, V. (2016): Diogenis fragmenta. Diogenove zlomky. Bratislava: Univerzita Komenského.

DESMOND, W. (2008): Cynics. Stocksfield: Acumen.

DUDLEY, D. R. (1937): A History of Cynicism. From Diogenes to the 6th Century A.D. London: Methuen.

FLACHBARTOVÁ, L. (2015): Diogenovský kynizmus ako spôsob života. Prešov: Filozofická fakulta Prešovskej univerzity.

GEUSS, R. (2001): Public Goods, Private Goods. Princeton: Princeton University Press.

GIANNANTONI, G. (ed.) (1990): Socratis et Socraticorum reliquiae.4 voll. Napoli: Bibliopolis (skratka SSR).

GOULET-CAZÉ, M.-O. (1982): Un syllogisme stoïcien sur la loi dans le doxographie de Diogène le Cynique. A propos de Diogène Laërce VI 72. Rheinisches Museum für Philologie, 125, 214 - 240.

${ }^{26}$ Na toto špecifikum Diogenovho kozmopolitizmu upozorn̆ujú Moles (1996, 112); Bosman (2007, $34)$; Haslanger $(2015,39)$. Spomeňme si na kynickú výzvu nechat' sa viest' príkladom zvierat, alebo na Diogena, ktorý sa vystavoval živlom: vyhrieval sa v lúčoch slnka, objímal zasnežené sochy a válal sa v rozpálenom piesku.

${ }^{27}$ Diog. Laert. VI 23[= SSR V B 174]. 
HADOT, P. (1995): Qu' est-ce que la philosophie antique? Paris: Gallimard.

HASLANGER, A. (2015): The Cynic as Cosmopolitan Animal. In: Nagai, K. et al. (eds.): Cosmpolitan Animals. Basingstoke; New York: Palgrave Macmillan, 29 - 42. DOI: https://doi.org/10.1057/9781137376282

HÖISTAD, R. (1948): Cynic Hero and Cynic King. Studies in the Cynic Conception of Man. Lund: Carl Bloms.

HOOK, B. S. (2005): Oedipus and Thyestes among the Philosophers. Incest and Cannibalism in Plato, Diogenes, and Zeno. Classical Philology, 100 (1), 17 - 40. DOI: https://doi.org/10.1086/431428

LIDDELL, H. G., SCOTT, R., JONES, H. S. (1968): A Greek-English Lexicon. Oxford: Clarendon.

LONG, A. A. (2008): The concept of the cosmopolitan in Greek \& Roman thought. Daedalus, 137 (3), 50 - 58. DOI: https://doi.org/10.1162/daed.2008.137.3.50

MOLES, J. L. (1996): Cynic Cosmopolitanism. In: Branham, R. B. - Goulet-Cazé, M.-O. (eds.): The Cynics. The Cynic Movement in Antiquity and Its Legacy. Berkeley - Los Angeles - London: University of California Press, $105-120$.

NAUCK, A., SNELL, B. (eds.) (1964): Tragicorum graecorum fragmenta. Hildesheim: Georg Olms.

OSBORNE, R. (2009): Greece in the Making. 1200 - 479 BC. Abingdon: Routledge.

PANGLE, T. L. (1998): Socratic Cosmopolitanism: Cicero's Critique and Transformation of the Stoic Ideal. Canadian Journal of Political Science, 31 (2), 235 - 262. DOI: https://doi.org/10.1017/S0008423900019788

PETRŽELKA, J. (2001): Katagelán v Platónových „sofistických“ dialozích. Pro-Fil, 2 (2).

ROSSETTI, L. (2010): I Socratici 'primi filosofi' e Socrate 'primo filosofo'. In: Rossetti, L. - Stavru, A. (eds.): Socratica 2008. Studies in Ancient Socratic Literature. Bari: Levante, 59 - 70.

SCHOFIELD, M. (1999): The Stoic Idea of the City. Chicago; London: The University of Chicago Press.

SUVÁK, V. (2000): Prečo by nemohla byt' filozofia ako filosofia, alebo o jednom malom nenápadnom „s“. Filozofia, 55 (5), 395 - 399.

ŠKVRNDA, F. (2016): Bol Antisthenés pýthagorovec? Filozofia, 71 (2), 96 - 106.

ŠKVRNDA, F. (2019): Sokrates a Télauges - Aischinova sokratika medzi platonizmom a kynizmom. Filozofia, 74 (1), 40 - 51. DOI: https://doi.org/10.31577/filozofia.2019.74.1.4

Príspevok vznikol ako súčast' riešenia grantového projektu VEGA 1/0864/18 Ad Fontes Cynicorum Socraticorum - pramene a interpretácia sokratovského kynizmu.

Jaroslav Cepko

Katedra filozofie

Filozofická fakulta Univerzity Mateja Bela

Tajovského 40

97401 Banská Bystrica

Slovenská republika

e-mail: jaroslav.cepko@umb.sk

ORCID ID: https://orcid.org/0000-0002-5232-8193 